\title{
The Management of Students with Special Needs in Inclusive School
}

\author{
Sujarwanto, Yatim Rianto, Muhammad Nurul Ashar \\ Universitas Negeri Surabaya \\ Surabaya, Indonesia \\ sujarwanto@unesa.ac.id
}

\begin{abstract}
The objectives of this research were to know the implementation of student management in inclusive school, and to know the supporting and inhibiting factors in its implementation. This research used a qualitative approach, with descriptive type of research. The data were collected through observation, interview, and documentation in public inclusive elementary school Ketintang II/410 Surabaya Indonesia. The informants were principal, classroom teacher, and special education teacher. The result of this research is that the implementation of student management is quite good in all aspects including planning, organizing, implementing, supervising, and evaluating. However, an aspect of planning still requires an improvement in the new student's registration team. Supporting factors in the implementation of student management are optimal support from various parties and inclusive culture that has been developed well, while inhibiting factors in student management are the direct support from parents and the lack of knowledge and experience of teachers.
\end{abstract}

Keywords-management, special needs, inclusive school

\section{INTRODUCTION}

Inclusive education is a growing trend in education today [1]. In Indonesia, inclusive education is embodied in inclusive school which is one of the alternative education services for students with special needs out of special school, as stated in Indonesia's Ministry of Education Regulation. An inclusive school is the school that organizes inclusive education system. The definition of inclusive education varies from country to country [2]. However, in general, inclusive education can be interpreted as an effort to overcome the discrimination of different students both because of the impairment, sociocultural differences, and different levels of economics [3]. In inclusive education system, either regular or disability students can learn the same school with still get supportive education services [4]. Further, based on several studies, the inclusive education system has a positive impact on several aspects such as optimal learning outcomes, and there is no bad influence on regular students [5]. Even the inclusive education is a social learning tool to introduce students to special needs [6]. Therefore inclusive school must make adjustments in school management [7].

One of the component in the implementation of inclusive education management in Indonesia that needs to be studied further is student management. It is based on research by [8] that shows, in terms of student management, there are still fundamental problems such as the limited quotas for students with special needs, and identification and assessment are not yet implement. Another result is shown by [9] where the quota of students with special needs is very excessive so that many students with special needs are disturbing other students during the learning process. In the [10] student management in inclusive schools include process: student admission (the implementation of the identification and assessment), student placement, tutoring programs and special services for students, and evaluation for students with special needs.

Related to the implementation of inclusive school student management in Indonesia so far there has been no research that examines this topic in depth. For example, research by $[11,12]$ on inclusive education management does not discuss in depth regarding student management. This is due to a wide range of research, covering all aspects of management in the implementation of inclusive schools. Therefore, this research aims to describe the implementation of student management in inclusive school in the aspect of planning, organizing, implementing, supervising, and evaluating as well as to know the supporting and inhibiting factors in the implementation of student management in inclusive school.

\section{METHOD}

This research used a qualitative approach, with descriptive type of research. The study was conducted in Inclusive Elementary Schools Ketintang II/410 Surabaya City, East Java Province, Indonesia. This school was selected because the number students with special needs are quite numerous and diverse, and spans from the grade I to class grade VI. Furthermore, this school has been implementing inclusive education for more than six years. Aspects studied in student management including planning, organizing, implementing, supervising, and evaluating. Coupled with factors that support and inhibit the implementation of student management. The research conducted for one month starting on February 13, 2017, until March 18, 2017. This research studied classes ranging from grade I to grade VI.

The research process starts from the preparation (research permit, and set for schedule), data collection, data analysis, conclusion and suggestion drawing. Data collection techniques used is through the observation, interview, and documentation. Non-participant observation was implemented during the 
learning over three times in grade I to grade VI using observation instruments. The interview was conducted in-depth with key informants as many as thirteen people included: principal, classroom teachers from grade I to VI, as well as a special education teacher from grade I to VI. The interview used open structured instruments.

The research design is shown in Figure 1. The design includes preliminary study, data collection process, data analysis, data validation, analysis data after validation, conclusion drawing and suggestion. The data were analyzed with [13], which includes the process of condensing the data (merging and strengthening data), data presentation, conclusion drawing, and verification.

Data were validated by the use of triangulation. Triangulation type used is source triangulation and technique triangulation [14]. Source triangulation is done through asking the same question to the different informant to get valid data. Technique triangulation was done by comparing data of interview, observation, and documentation.

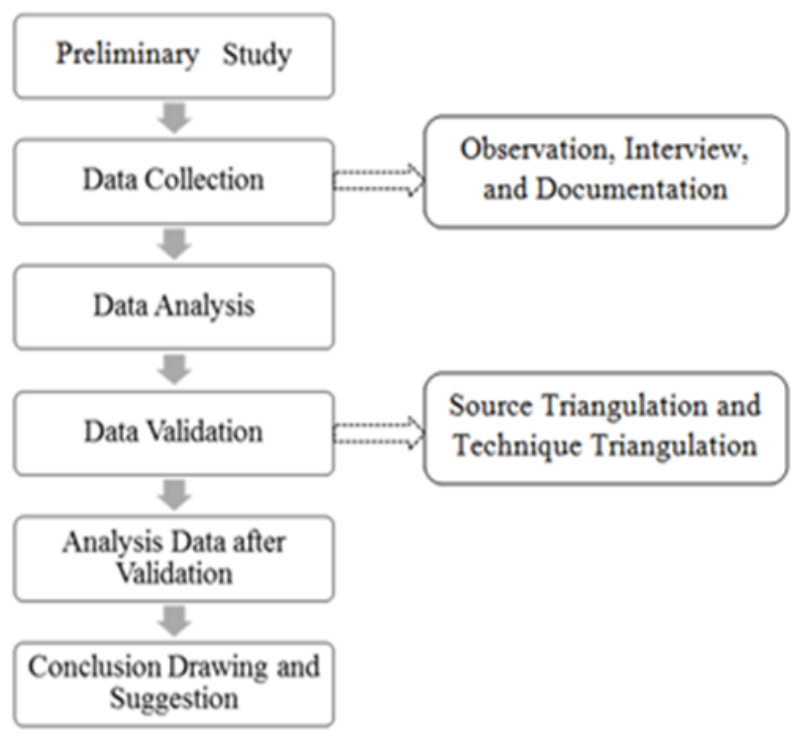

Fig.1 Research design

\section{RESULT AND DISCUSSION}

The results of the research are the results of data analysis after validation, and also the result of data condensation from all research subjects through the three techniques of data collection that is: observation, interview, and documentation. In brief, the results of the study based on the aspect of students management and supporting an inhibiting factor in the implementation of students management are shown in Table 1.

TABLE I. RESULT OF THE RESEARCH

\begin{tabular}{|c|c|c|}
\hline No & $\begin{array}{c}\text { Aspects of Student } \\
\text { Management }\end{array}$ & \multicolumn{1}{c|}{ Results } \\
\hline 1 & Planning & $\begin{array}{l}\text { Student management planning was done } \\
\text { through forming new students reception } \\
\text { team involving special education teacher, } \\
\text { also prepared special forms need to be filled } \\
\text { by parents of students with special needs. }\end{array}$ \\
\hline
\end{tabular}

\begin{tabular}{|c|c|l|}
\hline No & $\begin{array}{c}\text { Aspects of Student } \\
\text { Management }\end{array}$ & \multicolumn{1}{|c|}{ Results } \\
\hline 2 & Organizing & $\begin{array}{l}\text { Determinating the class service for each } \\
\text { student with special needs through } \\
\text { discussions between the classroom teacher, } \\
\text { special education teacher, with the approval } \\
\text { of the principal. }\end{array}$ \\
\hline 3 & Implementation & $\begin{array}{l}\text { Mentoring and guiding each student with } \\
\text { special needs, as well as the implementation } \\
\text { of peer tutoring during the learning in the } \\
\text { classroom. }\end{array}$ \\
\hline 4 & Supervising & $\begin{array}{l}\text { A brief, non-formal discussion with parents, } \\
\text { as well as with class teachers and special } \\
\text { education teachers. }\end{array}$ \\
\hline 5 & Evaluating & $\begin{array}{l}\text { Monthly activity reports to the Surabaya } \\
\text { City Education Board, evaluation with the } \\
\text { principal, and discussion with parents at } \\
\text { least once each semester. }\end{array}$ \\
\hline 6 & $\begin{array}{l}\text { Supporting Factors } \\
\text { Adequate support from school members } \\
\text { includes principal, classroom teachers, } \\
\text { subject teachers, regular students, as well as } \\
\text { school employees. Further support from the } \\
\text { Education Board through training programs } \\
\text { is also sufficient. }\end{array}$ \\
\hline Factors & $\begin{array}{l}\text { Support from parents is still } \\
\text { inadequate. Some teachers still have limited } \\
\text { knowledge and experience in the } \\
\text { management of student in inclusive schools. } \\
\text { Furthermore, the number of students with } \\
\text { special needs is also too much. }\end{array}$ \\
\hline
\end{tabular}

Based on the data in Table 1, it can be seen that planning aspect on student management was conducted by forming team for new students registration involving special education teachers, as well as setting up a special form that contains the identity of the student, physical condition, birth history, developmental history, education history, history of treatment, as well as data of parents and family. The formation of the team for new students registration involving special education teachers is good enough but should be able to involve other experts such as psychologists and doctors, to add the necessary information in the making of special programs for students [15]. Also, special form is appropriate and meets the criteria to obtain preliminary information on students with special needs, as stated by [16] that in general, the data that should be known about students with special needs when registering is the developmental history and services received.

The aspect of student management organization has been executed well because the school is already holding determination for class service for each student with special needs through the process of discussion. As explained in the $[10,17]$ the need for class services tailored to the ability of students with special needs including full regular classes, regular classes with special education teachers (cluster and pull out), as well as full special classes.

In the aspect of the implementation of student, management is good enough because the special education teachers give special guidance, and apply the principle of peer tutoring. This is in accordance with the opinion of $[18,19]$ who stated the importance of a social-emotional approach to special needs students, which manifested in the development of positive relationships between teachers and students or between students and students. 
Meanwhile, the supervision aspect has also been good because it involves many people such as parents, classroom teachers, as well as special education teachers. As explained by [20] that it is important to monitor continuously the implementation of student management in inclusive schools.

Aspects of evaluation of student management in the school are well enough, as evaluated by various parties ranging from the Education Board, principal, and parent. This is in line with the opinions by [21] which reveals the importance of individual and team evaluation by evaluating at least monthly, and collaborating with other.

Factor supporting the implementation of student management in Inclusive Elementary Schools Ketintang II/410 is adequate to support from the school community as well as the Board of Education. This fact is confirmed by the opinions of [22] which revealed that the culture/environment plays an important role in understanding the differences in order to achieve a better inclusive education implementation. More specifically, the principal has a vital role in implementing student management, through awareness and establishing cooperation with the whole school community [23, 24].

While the inhibiting factor in the implementation of student management is teachers lack of knowledge and experience in the management of student in inclusive school. In fact, teachers have an important role in the student management, and even become one of the indicators of success in the implementation of inclusive education [4, 25]. Furthermore, the role of parents is also important in supporting student management. Parent's understanding and the suggestion are essential to support the implementation of the inclusive education system in schools [26]. But unfortunately, the role of parents in schools that became the object of research is still less optimal.

\section{CONCLUSION}

The implementation of student management in inclusive the school that this research studied, in general, is quite good, especially in the aspect of organizing, implementing, supervising, and evaluating. The planning aspect still requires improvement in the team involved in the registration of the new students. Furthermore, supporting factors in the implementation of student management are optimal support from various parties and inclusive culture that has been developed well. Meanwhile, inhibiting factors in student management are the direct support from parents and the lack of knowledge and experience of teachers. The findings that need to be addressed are how the effective parent roles in the implementation of student management in inclusive schools as well as a model to develop knowledge and skills for classroom teachers and special education teachers in applying student management in inclusive schools.

\section{REFERENCES}

D. L. Ferguson, "International trends in inclusive education: The continuing challenge to teach each one and everyone," European Journal of special needs education, vol. 23, pp. 109-120, 2008. A. J. Artiles, "Toward an interdisciplinary understanding of educational equity and difference:
The case of the racialization of ability," Educational Researcher, vol. 40, pp. 431-445, 2011.

[3] F. R. Waitoller and A. J. Artiles, "A decade of professional development research for inclusive education: A critical review and notes for a research program," Review of Educational Research, vol. 83, pp. 319-356, 2013.

[4] A. Dagnew, "Factors affecting the implementation of inclusive education in primary schools of Bahir Dar Town administration," Educational Research Journal, vol. 3, pp. 59-67, 2013.

[5] S. J. Salend and L. M. Garrick Duhaney, "The impact of inclusion on students with and without disabilities and their educators," Remedial and special education, vol. 20, pp. 114-126, 1999.

[6] T. Shakespeare and N. Watson, "The social model of disability: an outdated ideology?," in Exploring theories and expanding methodologies: Where we are and where we need to go, ed: Emerald Group Publishing Limited, 2001, pp. 9-28.

[7] M. Yusuf and M. Rachman, "THE DEVELOPMENT OF INCLUSIVE EDUCATION MANAGEMENT MODEL TO IMPROVE PRINCIPALS AND TEACHERS PERFORMANCE IN ELEMENTARY SCHOOLS," The Journal of Educational Development, vol. 2, 2014.

[8] M. Yusuf and J. L. Yeager, "The implementation of inclusive education for students with special needs in Indonesia," Excellence in Higher Education, vol. 2, pp. 1-10, 2011.

[9] F. A. Hadis, "Toward inclusive, inclusive education in Indonesia: A country report," Seisa University, 2005.

[10] Team, Indonesia's General Guide of Inclusive Education Implementation. Jakarta: Ministry of Education and Culture, 2011.

[11] S. Dewi, A. Ekadinata, F. Johana, I. Khairuddin, and S. Gradstein, "Towards inclusive, integrative and informed spatial planning in Aceh Barat," in International Symposium on 'Land Use after the Tsunami-Supporting Education, Research and Development in the Aceh Region, Banda Aceh, 2008.

[12] I. Kaplan, I. Lewis, and P. Mumba, "Picturing global educational inclusion? Looking and thinking across students' photographs from the UK, Zambia and Indonesia," Journal of research in special educational needs, vol. 7, pp. 23-35, 2007.

[13] M. B. Miles, A. M. Huberman, and J. Saldana, "Qualitative data analysis: A method sourcebook," CA, US: Sage Publications, 2014.

[14] J. W. Creswell and D. L. Miller, "Determining validity in qualitative inquiry," Theory into practice, vol. 39, pp. 124-130, 2000.

[15] L. T. Eisenman, A. M. Pleet, D. Wandry, and V. McGinley, "Voices of special education teachers in an inclusive high school: Redefining 
responsibilities," Remedial and Special Education, vol. 32, pp. 91-104, 2011.

[16] J. Kurth and A. M. Mastergeorge, "Individual education plan goals and services for adolescents with autism: Impact of age and educational setting," The Journal of Special Education, vol. 44, pp. 146160, 2010.

[17] N. Zigmond, "Where should students with disabilities receive special education services? Is one place better than another?," The Journal of special education, vol. 37, pp. 193-199, 2003.

[18] M. Ainscow, "The ron gulliford lecture: The next step for special education: Supporting the development of inclusive practices," British Journal of Special Education, vol. 27, pp. 76-80, 2000.

[19] R. M. Gargiulo, Special education in contemporary society: An introduction to exceptionality: Sage Publications, 2010.

[20] W. Mitiku, Y. Alemu, and S. Mengsitu, "Challenges and opportunities to implement inclusive education," Asian Journal of Humanity, Art and Literature, vol. 1, pp. 118-135, 2014.

[21] S. K. Dymond, E. J. Chun, R. K. Kim, and A. Renzaglia, "A validation of elements, methods, and barriers to inclusive high school service-learning programs," Remedial and Special Education, vol. 34, pp. 293-304, 2013.

[22] V. Harwood, "The place of imagination in inclusive pedagogy: Thinking with Maxine Greene and Hannah Arendt," International journal of inclusive education, vol. 14, pp. 357-369, 2010.

[23] N. L. Waldron, J. McLeskey, and L. Redd, "Setting the Direction: The Role of the Principal in Developing an Effective, Inclusive School," Journal of Special Education Leadership, vol. 24, pp. 51-60, 2011.

[24] K. F. Poon-McBrayer and P.-m. Wong, "Inclusive education services for children and youth with disabilities: Values, roles and challenges of school leaders," Children and Youth Services Review, vol. 35, pp. 1520-1525, 2013.

[25] B. Levin, "Putting students at the centre in education reform," Journal of educational change, vol. 1, pp. $155-172,2000$.

[26] A. Doménech and O. Moliner, "Families beliefs about inclusive education model," Procedia-Social and Behavioral Sciences, vol. 116, pp. 3286-3291, 2014. 